Int. J. Dev. Biol. 58: 457-467 (2014)

doi: $10.1387 / \mathrm{ijdb} .140154 \mathrm{es}$

\title{
Variation in spiralian development: insights from polychaetes
}

\author{
ELAINE C. SEAVER* \\ Whitney Laboratory for Marine Bioscience, University of Florida, FL, USA
}

\begin{abstract}
Spiralian development is characterized by the conservation of spindle orientation and cell geometry during early cleavage stages, as well as features of the ultimate fates of identified cells. This complex set of characters is shared by a number of animal lineages including nemerteans, polyclad platyhelminthes, annelids and mollusks. How a similar, highly stereotypical cleavage program can give rise to such diversity of larval and adult forms has intrigued researchers for many years. This review summarizes recent data from polychaete annelids, and highlights both conservation and variation in the cellular and molecular mechanisms that guide the spiral cleavage developmental program. There is a specific focus on comparisons of fate maps, patterns of cleavage, mechanisms of cell fate specification, organizing activity, and differences in molecular patterning. Some of the differences in early development represent intra-clade variation within annelids, and others hint at differences between annelids and other taxa. Because much of the classic work on spiralians has focused on mollusks, these new data from annelids have expanded our knowledge about the evolutionary flexibility in spiralian development and potentially its role in body plan evolution.
\end{abstract}

KEY WORDS: spiralian, polychaete, fate specification

\section{Introduction}

Following fertilization, the zygote divides repeatedly and often rapidly into numerous smaller cells or blastomeres, preparing the embryo for important later events such as gastrulation. Cleavages are often tightly regulated during animal development, and indeed in many, but not all groups of animals, the details of the early cleavage program are highly stereotypic from embryo to embryo and from the offspring of one adult to another. This stereotypy has both practical and phylogenetic implications. Practically, it can allow for the unambiguous identification of individual cells in the embryo, and fate maps (the complete set of descendants derived from a particular identified cell) can be constructed for each cell. In addition, experimental manipulations of identified cells can be performed to determine the stability of cell fate and timing of cell fate specification. Animals such as soil nematodes, urochordate ascidians, and ctenophores have been extensively studied to learn how these stereotyped cleavage programs segregate developmental potential. Induction events and complex regulatory networks that control early developmental events have also been examined in animals with stereotypic cleavage programs.

Because cleavage programs are often characteristic of particular animal clades, they have also been used to make phylogenetic inferences as to common lines of evolutionary descent. A classic example is the existence of a stereotyped pattern of early develop- ment called spiral cleavage. This pattern of development can be recognized by the arrangement, relative size and position of the blastomeres. Conserved fate maps and similar larval forms also characterize spiralian development. Spiral cleavage is shared by a number of taxa that exhibit a huge diversity of adult animal forms, including the mollusks (snails and bivalves) annelids (earthworms and leeches), nemerteans (ribbon worms), flatworms (polyclad flatworms) and other invertebrate taxa. Animals exhibiting spiral cleavage diverged over 500 Myr ago, and researchers have been struck by the similarities in their early development for over 100 years. In a paper written in 1898, titled "Considerations on celllineage and ancestral reminiscence", E. B. Wilson noted that the development of these animals was so alike that their similarities could not be explained by chance, but must be due to a shared evolutionary past (Wilson, 1898). Wilson's postulation has been confirmed by a number of recent phylogenomic studies that support the Spiralia (Dunn et al., 2008, Edgecombe et al., 2011, Hejnol et al., 2009, Philippe et al., 2009, Struck et al., 2014).

The predictability in position, size, and timing of cell divisions in the spiralian developmental program allows homologous cells in the early embryo to be identified and compared across taxa. Thus, the evolution of cell lineages and specification of cell fate can be studied. However, the extraordinary conservation of early development in spiralians raises an apparent paradox: how does such a similar, highly stereotypical cleavage program give rise to such

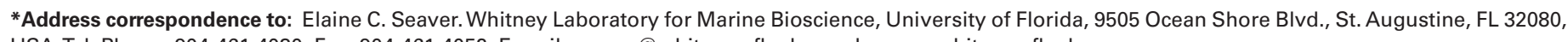
USA.Tel: Phone: 904-461-4030. Fax: 904-461-4052. E-mail: seaver@whitney.ufl.edu - web: www.whitney.ufl.edu

Accepted: 20 June 2014

ISSN: Online 1696-3547, Print 0214-6282

(C) 2014 UBC Press

Printed in Spain 
A
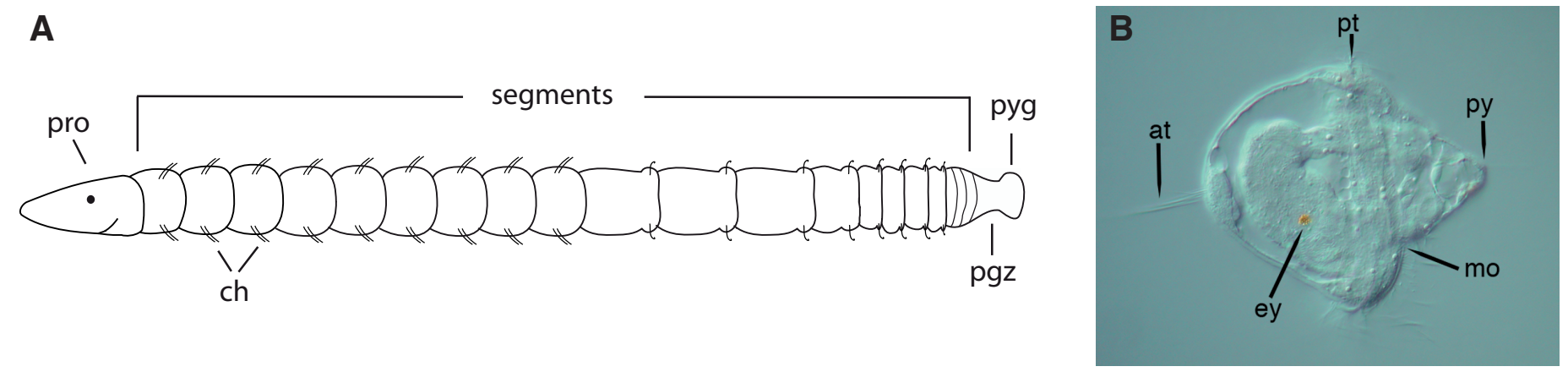

Fig. 1. Annelid adult and larval form. Anterior is to the left in both panels. (A) Schematic of the adult annelid body plan (B) Trochophore larva. DIC image of a live Hydroides elegans trochophore larva. At, apical tuft; ey, eye; mo, mouth; py, pygidium; pt, prototroch.

diversity of larval and adult forms? Do clade-specific differences arise only at later stages in development, after gastrulation, or is there significant clade-specific variation at early stages that is tied to morphological differences among larval or adult forms? How and when do molecular differences that give rise to novel phenotypes become established during these early cleavages? Most spiralian embryological studies have focused on gastropod mollusks, and the consequences of changes in the spiralian cleavage program on body plan evolution have thus far only been documented in a few cases. Extreme cases of variation include examples of losses of the spiralian cleavage program within sublineages of animal groups with spiral cleavage. These include cephalopod mollusks that have extremely large eggs and cleavages occur only on the animal pole as a disc of cells (Wadeson and Crawford, 2003), and the embryos of some neoophoran platyhelminthes in which blastomeres become separated from each other by surrounding yolk cells (Thomas, 1986). The lophophorates (e.g. phoronids and brachiopods) also show little or no trace of the spiralian program. There is limited data on molecular mechanisms that control spiralian development. Spiralian taxa are thus fertile ground for modern embryological and molecular studies aimed at understanding the evolution of developmental programs and how developmental changes can give rise to morphological diversity.

\section{Annelids}

One of the more speciose, but understudied groups of animals exhibiting spiral cleavage is the Annelida. Commonly referred to as the 'segmented worms', annelids are one of three major animal groups with a segmented body (Seaver, 2003). There are over 20,000 described species, and annelids exhibit a diversity of form, life history and habitat, and they are particularly dominant in the marine environment. The typical annelid body plan includes a presegmental region in the head (the prostomium), containing the brain and anterior sense organs (Rouse and Pleijel, 2001). Posterior to the prostomium are numerous serially-repeated segments in the trunk, and a terminal, posterior non-segmental pygidium (Fig. 1A). Many annelids have segmental appendages containing bristles or chaetae. Segment and appendage morphology can be very similar among segments within an individual (homonomy), vary substantially (heteronomy), or any combination in between. Most annelids form new segments from a sub-terminal posterior growth zone, located immediately anterior to the pygidium. Segments are often continually added throughout the lifetime of the animal, with the majority of segments generated during juvenile and adult stages. Segment number differs widely across species and often even between individuals of the same species. Thus, many annelids lack a determinate number of segments. Annelids exhibit a diversity of life history strategies and many have an indirect life cycle, producing a pelagic larval form called the trochophore (Fig. 1B), followed by metamorphosis into a juvenile worm. Also known for their extensive regenerative abilities, most annelids display robust posterior regeneration, and some display both anterior and posterior regeneration capabilities (Bely, 2006; Bely, 2014). Variation of annelid features such as the spiral cleavage program, life history, and the ability to regenerate will undoubtedly reveal further insights into the evolution of animal body plans and the bilaterian ground pattern.

Phylogenetic relationships among annelids are not well agreed upon. Deep-level relationships in Annelida have been difficult to reconstruct due to rapid evolution. Recent efforts to resolve these nodes have utilized phylogenomic approaches and more comprehensive taxon sampling. Traditional annelid phylogenies included the clitellates and polychaetes. The clitellates are comprised of the leeches and oligochaetes, so named because members deposit their eggs into a cocoon secreted by a glandular structure called the clitellum (Shankland and Savage, 1997). Both morphological and molecular data support the monophyly of the clitellates, and numerous molecular studies place the clitellates within the polychaetes, rendering Polychaeta paraphyletic. Clitellates undergo direct development, and share a highly stereotyped, but modified, form of spiral cleavage (Shankland and Savage, 1997). In this review, we use the informal term polychaetes to refer to non-clitellate annelids, following Rouse and Pleijel (Rouse and Pleijel, 2001).

Multiple molecular phylogenetic studies position echiurans and pogonophorans (siboglinidae) as derived annelids; these taxa were previously treated as separate phyla (reviewed in (Halanych et al., 2002). There is also increasing support for the inclusion of sipunculans within annelids, although their exact position is still uncertain (Giribet, 2008, Hejnol et al., 2009, Struck et al., 2011, Struck et al., 2007). Both echiurans and sipunculans exhibit spiral cleavage. Echiurans and sipunculans do not display overt adult body segmentation, and the inclusion of these groups within the Annelida implies that segmentation is more evolutionarily plastic than has previously been appreciated. Two recent phylogenomic studies group most annelids into one of two clades, the Errantia (active errant polychaetes) and the Sedentaria (sedentary polychaetes) (Struck et al., 2011, Weigert et al., 2014). However, these analyses show branching of several morphologically diverse annelid taxa sister to these two supergroups, leaving features of the ancestral 
annelid difficult to reconstruct. Hopefully as additional analyses are published, further support for which annelid taxa should be placed at the base of the annelid tree will be supported.

Two polychaete species are emerging as models for studies of spiralian development, Capitella teleta and Platynereis dumerilii. Both species have advantages for developmental studies including the fact that they can be readily cultured in the laboratory, embryos and larvae can be obtained on a regular basis, and numerous molecular and functional techniques have been established. Capitella and Platynereis exhibit an early cleavage pattern representative of other spiralians, and both undergo unequal cleavage (Fig . 2) (Eisig, 1899, Fischer and Arendt, 2013, Seaver et al., 2005). Although the exact phylogenetic relationship between Capitella and Platynereis may not be completely resolved, they are not close sister taxa, and there are numerous differences between their larval and adult body plans as well as their life histories (Thamm, 2007). These differences include: 1/ the segments in Platynereis adults are morphologically identical, while the Capitellabody is divided into distinct thoracic and abdominal regions; 2/ Platynereis reproduces only once, whereas Capitella females can generate an average of 4-6 broods; 3/ approximately 2000-3000 $160 \mu \mathrm{m}$ eggs are produced for each spawn in Platynereis, whereas approximately 200200 um eggs are present in each Capitella brood; 4/ during the larval period, Platynereis generates three larval segments and Capitella generates 13; 5 / metamorphosis gradually occurs over a period of several days in Platynereis and in Capitella it occurs within hours; 6/ the life cycle is approximately 6 months in Platynereis and 8-10 weeks in Capitella. The Capitella genome sequence is currently the only full genome sequence available for any polychaete. The differences between these two polychaete annelids highlight the importance of continued comparisons between these two rather than emphasis of a single model.

\section{The spiralian cleavage program}

During spiral cleavage, the first two holoblastic cell divisions generate the four embryonic quadrants: called the A, B, C, and D blastomeres. Some species undergo what is known as 'unequal cleavage', in which the first cell division gives rise to a smaller $A B$ cell and a larger $C D$ cell. At the next division, $A B$ divides equally to give rise to two equal sized blastomeres ( $A$ and $B$ ), and the $C D$ cell divides unequally to generate a smaller $\mathrm{C}$ blastomere and a larger D blastomere (Fig. 3A). These asymmetric divisions allow the unambiguous identification of cells from the time of their birth. At the third cell division, the four blastomeres divide obliquely with respect to the animal-vegetal axis to generate a quartet of smaller cells (micromeres) towards the animal pole (Fig. 3 A,B). The larger cells (macromeres) have a vegetal position. Subsequent rounds of divisions of the macromeres generate additional quartets of micromeres, with mitotic spindles oriented clock-wise and counter-clock-wise when the embryo is viewed from the animal pole, at alternating $90^{\circ}$ angles. The first set of micromeres born is designated as the first quartet of micromeres, and the second set as the second quartet of micromeres, and so on. Most embryos give rise to four quartets of micromeres. There is a standard nomenclature to identify each blastomere in the embryo (Conklin, 1897). Micromeres are named with a small letter referring to the embryonic quadrant of origin along with a number reference to indicate the first (1a, 1b, 1c, 1d) or second quartet of micromeres $(2 \mathrm{a}, 2 \mathrm{~b}, 2 \mathrm{c}, 2 \mathrm{~d})$, etc. Macromeres are named with capital letters of their quadrant of origin along with a number to indicate which quartet of micromeres was most recently born (Fig. 3C). When the micromeres divide, the daughters inherit the name of the mother cell along with either a superscript '1' to refer to the cell positioned to the animal side, and a superscript ' 2 ' to refer to the vegetal sister cell.

\section{Spiralian fate maps}

In addition to conserved cleavage patterns that allow the lineage of each cell to be followed through development, blastomere fates are also highly conserved across spiralian clades. Two modern but distinct approaches have been utilized to map cell fates. In one approach, the cell of interest is directly microinjected with an intracellular lineage tracer that is inherited only by daughters of the injected cell. This allows for both the documentation of the cleavage pattern over time as well as the ultimate differentiated fates of the descendant clone. In some cases, a second injection of a different lineage tracer can allow for additional resolution of a particular subclone. Modern fate mapping in spiralians by intracellular injection of lineage tracers was initiated in leech embryos (Weisblat et al., 1978, Weisblat et al., 1980). A second technique, called 4D microscopy, utilizes time-lapse imaging to follow individual cells using a semi-automated cell tracking system (Schnabel et al., 1997). This methodology requires optically clear embryos and gives detailed cell division information, but there is limited or no
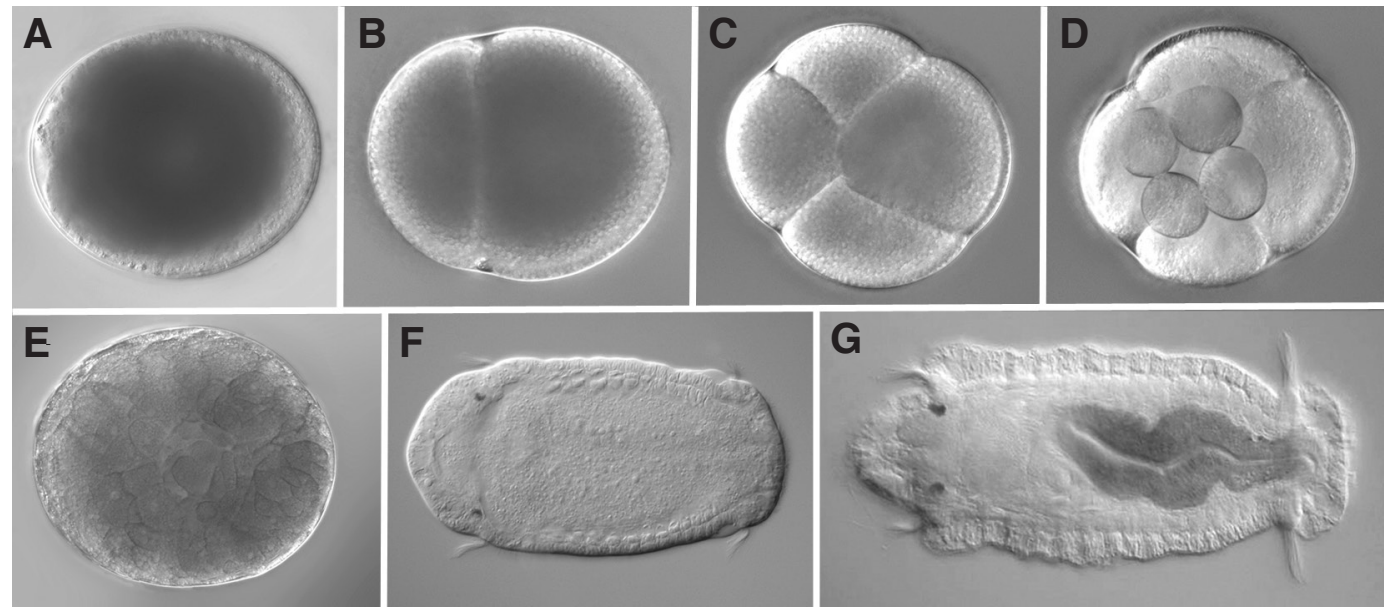

Fig. 2. Capitella development. Developmental series of embryonic and larval stages. All panels are DIC images, and each panel was generated from micrographs from a series of multiple focal planes. (A,B,D) animal view; $(\mathbf{C}, \mathbf{E})$ vegetal view; $(\mathbf{F}, \mathbf{G})$ ventral view. The following stages are shown: (A) 1-cell stage, (B) 2-cell stage, (C) 4-cell stage, (D) 8-cell stage, (E) gastrula, (F) St. 5 larva, (G) St. 9 larva. 
information on ultimate fates of cells if the specimen moves during the developmental period examined.

Widely shared features can be used to describe a generalized spiralian fate map. Both classical and modern studies from a range of taxa have contributed to our understanding of shared features of spiralian fate maps, including several classical studies in annelids. The earliest cell lineage study for any spiralian was performed by Whitman using the leech Clepsine (Whitman, 1887). Additional studies include detailed lineage analyses for Nereis (Wilson, 1892), Chaetopterus (Lillie, 1906, Mead, 1897), Capitella (Eisig, 1899), Dinophilus (Nelson, 1904), and Podarke (Treadwell, 1901). In most spiralians, cells derived from the A, B, C and D blastomeres roughly approximate the left, ventral, right, and dorsal quadrants of the body, respectively, although the relationships between the boundaries of the descendant clones and the body axes are variable across species (Shankland and Seaver, 2000). In addition, the alternating position of each quartet of micromeres shifts the position of descendants. Anterior head ectoderm arises from the first quartet micromeres. Of these, $1 \mathrm{a}$ and $1 \mathrm{c}$ generate the left and right larval eyes, respectively. Another conserved feature that originates from the first quartet is the major ciliated band of the larva, the prototroch (velum in mollusks), which comes primarily from the $1 q^{2}$ cells. Two cells from the $D$ quadrant, $2 d$ and $4 d$, have particular importance in that they make disproportionate contributions to the body. Also known as the primary somatoblast, $2 \mathrm{~d}$ generates the majority of the trunk ectoderm; in annelids, this includes all of the body segments (and the pygidium in polychaetes). 4d, the 'mesentoblast', generally generates the trunk mesoderm, part of the endoderm ("hindgut") and is proposed to be the origin of the germline. Most of the larval and adult endoderm ("midgut") is derived from the vegetal macromeres.

In polychaetes, there are only four modern cell lineage or fate mapping studies published to date, including two studies each for Capitella teleta (Meyer et al., 2010, Meyer and Seaver, 2010) and Platynereis dumerilii (Ackermann et al., 2005, Fischer and Arendt, 2013). In one Platynereis study, identified blastomeres were microinjected for a limited set of blastomeres $\left(1^{\text {st }}\right.$ quartet micromeres, $1^{\text {st }}$ quartet macromeres, $2 d^{112}, 4 d$ and $4 d^{1}$ ), and several features

A
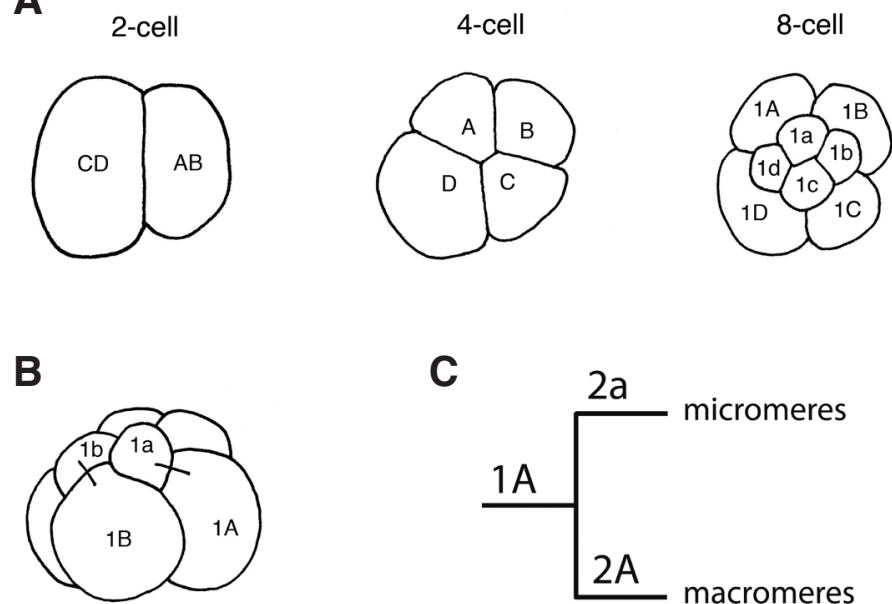

Fig. 3. Schematic of spiral cleavage (A) Unequal spiral cleavage. (B) Lateral view of an 8-cell embryo showing the orthogonal orientation of the cleavage spindles with respect to the animal-vegetal axis. Two mother-daughter pairs are labeled. (C) Branching diagram showing nomenclature of mother and daughter cells.

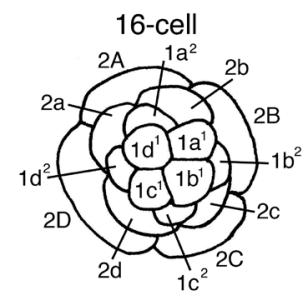

of the fate map were inferred by subtractive logic (Ackermann et al., 2005). A second Platynereis study utilized 4D microscopy to examine cleavage patterns (Fischer and Arendt, 2013). With a few notable exceptions (see below), conserved features of the spiralian fate map hold true for the polychaete embryos that have been examined by either classical or modern methods.

Two studies provide a comprehensive analysis of the origin of larval and adult tissues for Capitella (Meyer et al., 2010, Meyer and Seaver, 2010). In one, all first (including $1 q^{1}$ and $1 q^{2}$ ), second, and third quartet micromeres, their corresponding sister macromeres, and $4 \mathrm{~d}$ were individually microinjected and their descendants followed into the larval period. Many details of the Capitellafate map fit with highly conserved features of the spiralian fate map. For example, the two larval eyes originate from $1 \mathrm{a}$ and $1 \mathrm{c}$, the prototroch comes from the $1 \mathrm{q}^{2}$ cells, and the somatoblast $2 \mathrm{~d}$ forms the vast majority of the post-trochal ectoderm (Meyer et al., 2010). In a second study, the sublineage or division patterns and fates of daughters of the primary somatoblast 2d was examined (Meyer and Seaver, 2010). This cell generates both larval (neurotroch and telotroch) and adult tissues (ventral nerve cord, epidermis). An intriguing result of this study is that larval fates are not segregated from adult fates in the first divisions of the $2 \mathrm{~d}$ sublineage. In the first division, $2 \mathrm{~d}$ divides to give rise to the more animal $2 d^{1}$ and the vegetal $2 d^{2} .2 d^{1}$ and $2 d^{2}$ both give rise to larval and adult tissues, although the $2 \mathrm{~d}^{1}$ clone is much larger and gives rise to all of the trunk ectoderm, the left neurotroch, the left telotroch and the left pygidial ectoderm (Fig. 4). $2 \mathrm{~d}^{2}$ generates the right neurotroch, right telotroch and right pygidial ectoderm. The division of $2 \mathrm{~d}^{1}$ generates $2 \mathrm{~d}^{11}$ and $2 \mathrm{~d}^{12} \cdot 2 \mathrm{~d}^{11}$ gives rise to the adult trunk, but does not generate any larval structures. $2 \mathrm{~d}^{11}$ generates the first bilateral clone in the $2 \mathrm{~d}$ sublineage. The other daughter cell $\left(2 d^{12}\right)$ generates a mirror clone of $2 d^{2}$, giving rise to the left telotroch, left neurotroch and left pygidial ectoderm. Direct injections of $2 \mathrm{~d}^{112}$ yield clones containing left and right trunk ectoderm that extends from the mouth to the telotroch. This clone is similar to the clone made by its mother cell, minus a region from the prototroch to the mouth. Following division of $2 \mathrm{~d}^{112}$, the cells $2 \mathrm{~d}^{1121}$ and $2 \mathrm{~d}^{1122}$ form the right and left trunk ectoderm, respectively. Because mollusks and clitellate annelids do not have a telotroch or neurotroch, this is the first modern report for the origins of posterior larval structures during spiralian development.

A surprising result of the Capitella fate map was the embryological origin of the mesodermal bands, which generate almost all of the trunk musculature (Meyer et al., 2010). In almost all published spiralian fate maps generated using intracellular lineage tracers, the mesodermal bands arise from $4 \mathrm{~d}$. In Capitella, the mesodermal bands instead arise from two cells, $3 c$ and $3 d$. Each of these cells generates a single mesodermal band, and the two descendant clones are mirror images. Thus, the trunk mesoderm arises from both the $C$ and $D$ quadrants, instead of solely from the $D$ quadrant. This finding was originally described by Eisig in his cell lineage study of Capitella capitata 


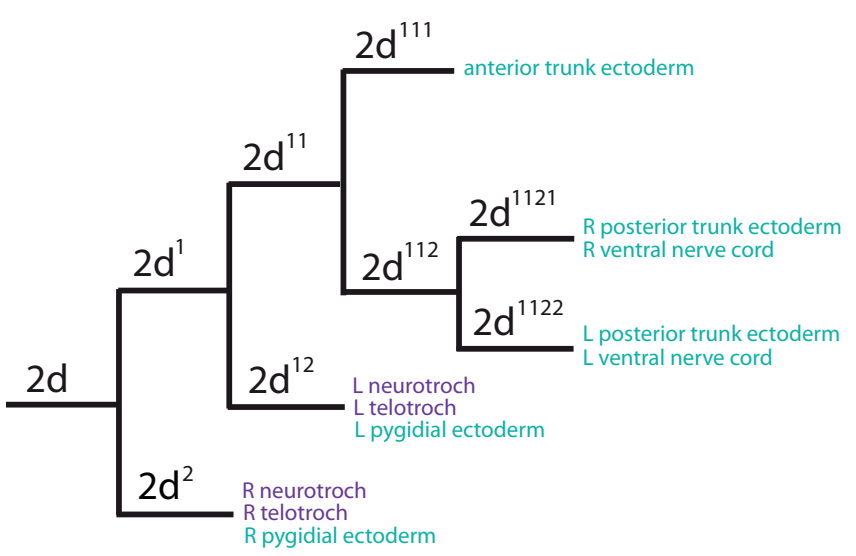

Fig. 4. Branching diagram of larval fates generated by $\mathbf{2 d}$ daughter blastomeres in Capitella teleta. $L$, left; $R$, right.

(Eisig, 1899), although his results were received with skepticism by his contemporaries (Nelson, 1904, Treadwell, 1901).

If $4 \mathrm{~d}$ does not generate the mesodermal bands in Capitella, one obvious question becomes, what does it generate? Are there features of the descendant clone that are shared with other spiralians? In Capitella, 4d generates a small number of longitudinal muscle fibers, putative primordial germ cells, and the anus, and these cell types are conserved descendants of $4 d$ in other spiralians. Therefore, there is an apparent evolutionary retention of some but not all features of the $4 d$ lineage. Since the mesodermal bands arise from 4d in Tubifex (Goto et al., 1999), Helobdella (Weisblat et al., 1984) and Platynereis (Ackermann et al., 2005), it is likely that the mesodermal bands arose from $4 \mathrm{~d}$ in the ancestral annelid. However, it will be important to sample additional species to determine how much variation exists in the origin of the mesodermal bands within annelids.

\section{Comparison of Capitella cleavage patterns of $\mathbf{2 d}$ and 4d with other spiralians}

It is not necessary to take up the divisions of $2 d$ in detail in the annelids. Anyone who will take the trouble to follow through the divisions of this cell in Unio, Crepidula, Nereis, Amphitrite and Arenicola will be convinced that differences are considerable and in some cases very great, so that after a few divisions there is no basis for a cell-homology among the descendants of 2d if similarity of origin is regarded as one of the criteria.

(Child, 1900)

In most spiralians, the micromeres $2 \mathrm{~d}$ and $4 \mathrm{~d}$ are relatively large cells, and together they generate the majority of the adult body. Because of their importance, their cleavage patterns have been characterized in detail for several species. The transition from spiral cleavage to a bilateral cleavage pattern often occurs in the $2 \mathrm{~d}$ and $4 d$ lineages, and thus, studies of the $2 d$ and $4 d$ cleavage programs have given insight into how an embryo that undergoes spiral cleavage generates a bilaterally symmetric animal, a problem that has intrigued researchers for years. In the polychaetes Capitella teleta and the three closely-related species Platynereis dumerilii, Platynereis massiliensisand Nereis limbata, the first bilateral division occurs after the same number of divisions, in the fourth division cycle of
$2 d$. This is when $2 d^{112}$ divides to produce the daughter cells $2 d^{1121}$ and $2 d^{1122}$ (Dorresteijn, 1990, Meyer and Seaver, 2010, Schneider, 1992, Wilson, 1892). From older observations, bilateral division of $2 \mathrm{~d}^{112}$ was also reported for the polychaetes Amphitrite (Mead, 1897) and Dinophilus (Nelson, 1904). The cleavage pattern of 2d has been characterized in extraordinary detail for several clitellates (reviewed by Dohle, 1999). In the oligochaetes Tubifex (Penners, 1922) and Eisenia (Devries, 1968, Devries, 1973), 2d ${ }^{112}$ divides equally to form the left and right precursors to the ectoteloblasts. However in the leeches Theromyzon (Sandig and Dohle, 1988) and Helobdella (Huang et al., 2002), although the fourth division cycle of $2 d$ represents the first bilateral division in the $2 d$ lineage, the blastomere that undergoes a bilateral division is $2 d^{222}$ instead of $2 \mathrm{~d}^{112}$. The conservation of the complex division pattern of $2 \mathrm{~d}$ is suggestive that polychaetes and oligochaetes share an ancestral pattern, and that leeches differ in this respect.

Within mollusks, significant variation occurs in the presence and timing of the first bilateral division in the $2 \mathrm{~d}$ sublineage. In Unio, bilateral division of the very large $2 \mathrm{~d}$ cell is during the fifth cleavage cycle, one division later than in annelids. In contrast to the Unio pattern, 2d itself divides symmetrically in Patella vulgata (Damen, 1994). In the snail Lymnea stagnalis, bilateral cleavages are initiated by the first quartet micromere $1 d^{121}$ instead in the $2 d$ sublineage (Verdonk, 1968), and in the slipper snail Crepidula, 2d sublineage divisions have been followed past the fourth division cycle, but only spiral cleavages were described (Conklin, 1897). The onset of bilateral divisions in the $2 d$ lineage is not currently known for Crepidula. The considerable variation seen in mollusks makes it difficult to determine the ancestral molluscan $2 \mathrm{~d}$ pattern.

Even though the fate of $4 \mathrm{~d}$ has been widely investigated and the $4 d$ fate is one of the most conserved features of spiralian development (Lambert, 2008), the cleavage pattern of the $4 d$ daughter cells has only been investigated in a limited number of cases using modern methods (Fischer and Arendt, 2013, Lyons et al., 2012). In annelids, the most detailed studies of $4 \mathrm{~d}$ sublineages are from the clitellates Helobdella and Tubifex using injection of intracellular lineage tracers (Gline et al., 2011, Goto et al., 1999, Zackson, 1982). Clitellates have a somewhat modified spiral cleavage program and a distinct nomenclature for identifying blastomeres; nevertheless, they provide an important framework for comparisons within annelids. The first two divisions of the mesodermal progenitor DM produces two small micromeres (dm' and dm") and then divides symmetrically to form the left and right mesoteloblasts, $M_{L}$ and $M_{R}$ (Bissen and Weisblat, 1989). These mesodermal teloblasts divide highly asymmetrically, and undergo iterated divisions to produce chains of smaller daughter cells that form the mesodermal bands. The earliest born daughter cells generate nonsegmental mesodermal structures in the head and associated with the gut (Gline et al., 2011), while subsequent daughters are founder cells that generate segmentally-repeated mesodermal structures. It is notable that the boundaries of these repeats do not coincide with segmental boundaries, and instead span multiple segments (Weisblat and Shankland, 1985).

A study in Platynereis dumerilii using 4D microscopy is the only modern characterization of the $4 \mathrm{~d}$ cleavage pattern for a polychaete (Fischer and Arendt, 2013). The first division of $4 d$ is bilaterally symmetrical, producing precursors of the left and right mesodermal bands $M_{L}$ and $M_{R}$. Subsequently, $M_{L}$ and $M_{R}$ each undergo seven sequential rounds of asymmetric division to produce a group of 
smaller cells all born in a column. Thus, the $4 \mathrm{~d}$ cleavage pattern in Platynereis is very similar to that of Tubifexand Helobdella, although it is unknown whether the smaller daughter cells are mesodermal founder cells. Later cell divisions of $M_{L}$ and $M_{R}$ in Platynereis become more symmetric, and the cleavage planes vary in their orientation with respect to the axes of the embryo.

The early cleavage patterns of $4 d$ in annelids contrast with $4 d$ division patterns observed in the mollusks Crepidula and Ilyanassa (Conklin, 1897, Goulding, 2001, Lyons et al., 2012, Rabinowitz et al., 2008). Following an initial bilateral division, the subsequent born $4 \mathrm{~d}$ granddaughter cells alternate in their position from one side to the other in the embryo, consistent with a spiral cleaving nature. This pattern continues for three rounds of divisions, after which daughters are produced on a single side. Although data for $4 \mathrm{~d}$ cleavage patterns come from limited sampling, the results are intriguing and hint at evolutionary modifications of the $4 \mathrm{~d}$ cleavage pattern following the divergence of annelids and mollusks. Additional detailed characterization of $4 \mathrm{~d}$ sublineages in other taxa, both within annelids and mollusks, as well as for others such as nemerteans are needed. It will also be important to identify fates of $4 \mathrm{~d}$ daughters in a range of species. From this information, it will be possible to identify correlations between birth order and descendent fate across species (e.g. in Crepidula, the first born daughter of $M_{L}$ or $M_{R}$ contributes to the hindgut and the second daughter contributes to the mesodermal bands), and identify clade-specific differences in cell fate determination.

\section{Embryonic organizing activity}

A hallmark of spiralian development is the presence of organizing activity from the $D$ quadrant. An embryonic organizer is a cell or group of cells that affects axial patterning or cell fate specification on other embryonic cells through an inductive signal. In spiralians, organizing activity was first identified in the mollusk Ilyanassa (Clement, 1962). Clement deleted individual blastomeres and analyzed the resulting larvae for patterning defects. Deletion of the 3D blastomere caused radialized larvae and micromere patterning defects. In contrast, deletion of either daughter of 3D (4d or 4D) resulted in defects derived from the missing cell, with little or no 'organizing influence' on adjacent cell lineages. Thus, the organizing activity in Ilyanassa is localized to a single cell (3D), and the timing of the signal occurs prior to the division of 3D into 4d and 4D. Later experiments on Crepidula identified $4 d$ as having organizing activity (Henry et al., 2006).

Until recently, systematic blastomere deletions had not been performed in polychaete embryos. The strongest indication that polychaetes have organizing activity came from experiments in which the first cleavage was equalized, resulting in the formation of double embryos in Chaetopterus and Nereis (Henry and Martindale, 1987, Tyler, 1930). Single cell laser deletions have proven to be a precise and reliable technique in Capitella (Pernet et al., 2012). In conjunction with a detailed knowledge of the fate map (Meyer et al., 2010, Meyer and Seaver, 2010), laser deletions were successfully used to identify an organizing activity in Capitella (Amiel et al., 2013). Following an extensive set of single blastomere deletions, larval phenotypes were analyzed by a combination of morphological features and molecular markers. In most cases, larvae were missing expected structures derived from the deleted blastomere, but were otherwise patterned normally. Surprisingly, no evidence for organizing activity was found for either the $4 d$ or 3D blastomeres, the cells with signaling activity in mollusks. Instead, organizing activity was localized to the primary somatoblast cell, $2 \mathrm{~d}$ (Amiel et al., 2013). Organizing activity by $2 d$ affected patterning of head structures and the establishment of the dorsal-ventral axis and bilateral symmetry, but did not affect formation of the anteriorposterior axis. The finding that deletion of both $2 \mathrm{~d}$ daughters, $2 \mathrm{~d}^{1}$ and $2 \mathrm{~d}^{2}$, resulted in formation of a normal dorsoventral axis and bilateral symmetry indicates that organizing activity occurs prior to the birth of these two cells (Amiel et al., 2013). The membrane of $2 d$ directly contacts all of the overlying target first quartet micromeres, suggesting that signaling may occur through direct cell-cell contacts. Organizing activity in Capitella is uncoupled from mesodermal fate, since deletions of the precursors of the mesodermal bands (3c and 3d) result in larvae with normal body axes (Amiel et al., 2013). In summary, experimental manipulations in Capitella demonstrate the presence of an embryonic organizer during annelid development.

The other annelid study that provides experimental evidence of organizing activity comes from grafting experiments in the oligochaete Tubifex, in which transplantation of $2 \mathrm{~d}^{11}$ plus $4 \mathrm{~d}$ from the $\mathrm{D}$ quadrant produces a second body axis (Nakamoto et al., 2011). It is difficult to determine the extent of organizing activity these cells might have during normal development however, because the grafted cells give rise to the duplicated ectodermal and mesodermal derivatives.

The differences in cellular identity and timing of organizing activity among species indicate a divergence of developmental pathway (Fig. 5). Although these differences are based on very limited sampling, the results raise several questions to guide future investigations. For example, is the identity of organizing activity in Capitella unique among annelids? It will be important to reconstruct the ancestral condition of the cellular identity of the organizing activity in annelids by surveying additional species, and include early branching polychaetes. More generally, it will be important to determine if

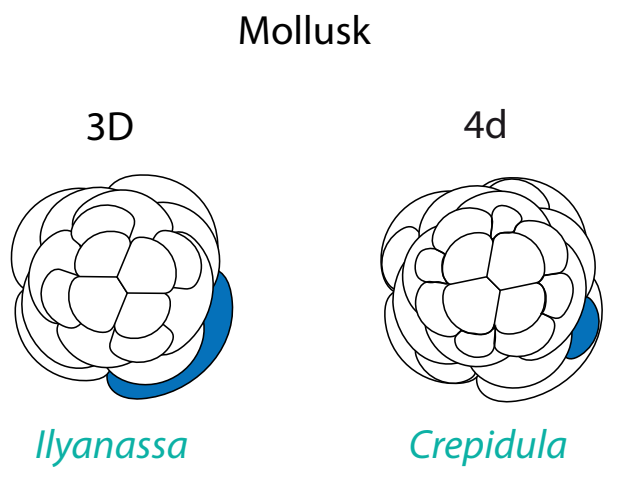

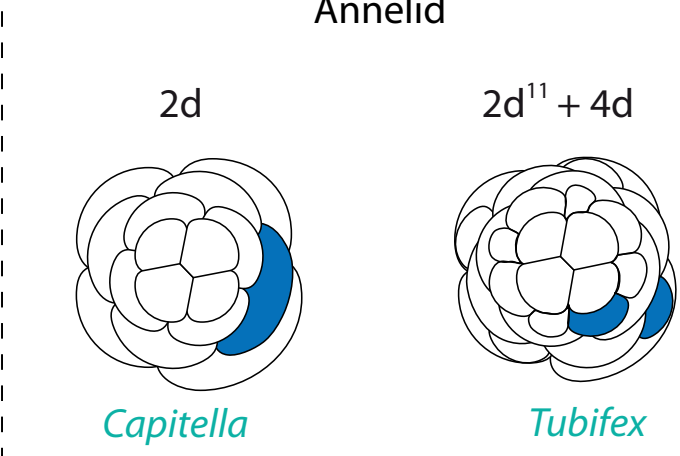

Fig. 5. Cellular identity of organizing activity in different spiralians. For each embryo schematic, the name of the cell with organizing activity is above the schematic, the animal name is listed below, and the cell with organizing activity is shaded. 
nemerteans, flatworms or sipunculids have organizing activity in order to address the question of whether organizing activity is a common (ancestral) feature of spiralian embryos. If organizing activity is a conserved spiralian feature, how much variation is there in its cellular identity? Is the organizing activity always localized to D quadrant descendants? To answer these questions, systematic deletions of individual blastomeres during early development is required for additional species, ideally for several representatives/ phylum. Such deletion information can only be interpreted within a framework of detailed fate map information for the same species.

\section{Developmental potential of the first quartet blastomeres}

For over 100 years, biologists have appreciated the importance of segregation of cytoplasmic determinants in specifying cell fates in the spiralian embryo. Demonstration of the importance of cytoplasmic determinants has come from manipulations such as raising isolated blastomeres, deleting blastomeres, and removing cytoplasmic regions such as the polar lobe. For most spiralians, particularly those that undergo asymmetric cleavages in the first two mitoses, isolated blastomeres develop into partial larvae, indicating a limited or an inability to regulate for missing structures. Raising isolated blastomeres to larval stages has been performed for the polychaetes Sabellaria (Novikoff, 1938, Render, 1997) and Nereis (Costello, 1945).

The polar lobe is an enucleate cytoplasmic protrusion on the vegetal side of some spiralian embryos that transiently forms during early cell divisions. It is used as a shunting mechanism to asymmetrically distribute cytoplasmic determinants. The polar lobe is most obvious during the first and second cell divisions; in the first division, the polar lobe material is shunted to the CD blastomere and in the second division to the $\mathrm{D}$ blastomere. Deletions of the polar lobe have provided evidence for inheritance of cytoplasmic determinants in the polychaetes Sabellaria (Novikoff, 1938, Render, 1983) and Chaetopterus (Henry, 1986), as well as in the mollusks Ilyanassa (Clement, 1952, Crampton, 1896) and Dentalium (Geilenkirchen et al., 1970, Wilson, 1904). Removal of the first and second cleavage polar lobes of Dentalium and Sabellaria embryos demonstrated a complex organization of polar lobe contents such that there was sequential inheritance of cytoplasmic determinants by the D quadrant with distinct functions. Render's experiments on Sabellaria (1983) were the first demonstration of inheritance of inhibitory material as a cellular mechanism of cell fate determination in spiralians. Specifically, inheritance of cytoplasmic determinants to the $\mathrm{D}$ quadrant prevented formation of the larval apical tuft by descendants of the D quadrant. Polar lobe removal from Chaetopterus embryos resulted in essentially normal larvae with loss of only bioluminescent photocytes (Henry, 1986), demonstrating that determinants can have a very specific function and affect only a single cell type. In summary, the segregation of cytoplasmic determinants is an important mechanism to specify blastomere fates in spiralians.

Other studies suggest the importance of inductive signals that together with inheritance of cytoplasmic determinants affect cell fate specification. As discussed in the previous section, identification of organizing activity represents an important example of inductive signaling in spiralian embryos. Another example comes from examination of eye-forming potential of first quartet micromeres in Ilyanassa (Clement, 1962, Sweet, 1998). Normally only 1a and 1c make eyes in Ilyanassa. When three of the four first quartet cells were deleted, with $1 \mathrm{~b}$ remaining, $1 \mathrm{~b}$ generates an eye. $1 \mathrm{~b}$ normally never makes eyes. When $1 \mathrm{~d}$ is the only remaining first quartet micromere, no eyes form. When $1 \mathrm{~b}$ is transplanted into the location of $1 \mathrm{a}$ or $1 \mathrm{c}$, it can generate an eye. In contrast, $1 \mathrm{~d}$ is not capable of generating eyes when transplanted, due to the inheritance of material from the polar lobe (Sweet, 1998). This study is highly significant because it was the first cell transplantation study in an indirect developing species to show that individual first quartet cells are not specified solely by inheritance of determinants, but instead are precisely positioned by the stereotyped cleavage program to receive inductive signals, in this case from the $\mathrm{D}$ quadrant macromere, 3D.

Cell fate specification of the larval eye by the first quartet of micromeres has also been investigated in Capitella (Yamaguchi and Seaver, unpublished data). Previous intracellular fate mapping experiments in Capitella have shown that the 1 a and $1 \mathrm{c}$ micromeres normally form the left and right eye, respectively (Meyer etal., 2010). When either 1a or 1c was removed by laser deletion, the resulting larvae usually had a single eye pigment spot, the expected result if $1 \mathrm{a}$ and $1 \mathrm{c}$ are the only two cells in the embryo with eye-forming potential. However, further analyses using a combination of cell deletion and cell-labeling experiments demonstrated that eye forming potential is not limited to $1 \mathrm{a}$ and $1 \mathrm{c}$. These experiments demonstrated that all four quadrants have the potential to generate an eye in Capitella, and hint at an inductive signal(s) necessary for specifying cell fate of the first quartet blastomeres. Determining the developmental potential of blastomeres in the early stage embryo may uncover variation among species not found from examination of fate maps, and may give insight into developmental flexibility in the embryo.

\section{Molecular signaling during early embryogenesis}

Despite the rich history of experimental embryology in spiralians, the molecular basis for axial patterning and cell fate specification has remained largely elusive. The demonstration that ERK/MAPK signaling is required in the $D$ quadrant for proper specification of axes and cell fates in llyanassa represented an important step towards revealing molecular mechanisms controlling early spiralian development (Lambert and Nagy, 2001). Subsequent studies showed that the MAPK pathway was specifically activated in the 3D blastomere in several other equal-cleaving mollusks, which may reflect specification of the D quadrant (Koop et al., 2007, Lambert and Nagy, 2003, Lartillot et al., 2002), although the pattern of MAPK activation is quite complex in Crepidula (Henry and Perry, 2008). Taking into account species-specific differences, it appears that activation of MAPK in the D quadrant is conserved among mollusks. In the polychaete Hydroides, activation of MAPK is only observed in $4 \mathrm{~d}$, though a role of this pathway in Hydroides development has not been experimentally tested (Lambert and Nagy, 2003).

In Capitella, ERK/MAPK activation does not appear to be involved in $D$ quadrant specification or axial patterning (Amiel et al., 2013). Activated MAPK is not detected in cleavage stage embryos, and the earliest expression is in cells associated with the blastopore lip during gastrulation. Furthermore, continuous exposure of embryos to an inhibitor of the MAPK/ERK pathway, UO126, results in larvae with normal body axes and head structures. Interestingly, a similar set of results was recently reported from a study in the polychaete Platynereis, in which activated MAPK was not detected until 
gastrulation, and embryos exposed to U0126 developed normal body axes (Pfeifer et al., 2014). In both Platynereis and Capitella, larvae resulting from UO125 treatment are shorter than normal and have a muscle pattern defects, with disorganized muscle fibers in Platynereis and a reduced number of muscle fibers in Capitella. These results suggest a similar function for MAPK/ERK signaling during later development for the two polychaetes. It is important to note that organizing activity has not yet been experimentally demonstrated in Platynereis. However, even if organizing activity is demonstrated for Platynereis, it is clear that the molecular signaling pathways utilized by Capitella and Platynereis are different from what has been demonstrated for several mollusks. This represents an example of divergence in genetic regulatory underpinnings of spiralian organizing activity. Additionally, it raises the question of whether organizing activity in mollusks and annelids is homologous.

The expression and role of $\beta$-catenin in early stage Platynereis embryos represents another interesting example of variation in molecular signaling among spiralians. During cleavage stages in Platynereis, $\beta$-catenin preferentially accumulates in the vegetal nuclei of sister blastomere pairs that divide along the animal-vegetal axis (Schneider and Bowerman, 2007). Ectopic activation of $\beta$-catenin by exposure to the drug Alsterpaullone increases nuclear localization of $\beta$-catenin in animal daughter cells. Two distinct cell fate transformations were demonstrated as a result. In the first, there was loss of the animal daughter fate following exposure of $4 \mathrm{~d}$ to Alsterpaullone, demonstrated by absence of larval trunk muscle (animal daughter fate). In the second example, there was loss of prototrochal cilia when $1 \mathrm{a}-1 \mathrm{~d}$ were exposed, and presumably there was a transformation to the vegetal sister cell fate. This pattern of nuclear $\beta$-catenin localization in vegetal daughters has not yet been reported for any other spiralian. It is notable that a similar pattern of binary segregation of activated $\beta$-catenin and cell fate specification occurs during blastomere cleavages oriented along the anterior-posterior axis in C. elegans (Kaletta et al., 1997, Lin et al., 1998). However, given the phylogenetic distance between Platynereis and $C$. elegans and the highly derived features of $\beta$ catenin signaling in $C$. elegans (Korswagen, 2002), it is likely that this superficial similarity represents an evolutionary convergence.

The role of nuclear $\beta$-catenin during early development has also been studied in the nemertean Cerebratulus (Henry et al., 2008). In this species, $\beta$-catenin is stabilized and becomes localized to the nucleus of endodermal precursors, the vegetal blastomeres. Morpholino knockdown of $\beta$-catenin blocks gastrulation in Cerebratulus. In addition, in resulting larvae there is loss of gut tissue and ectopic ectodermal structures. In contrast, expression of constitutively active $\beta$-catenin results in expansion of endodermal fate. $\beta$-catenin has a role in endoderm specification in several animal taxa, including cnidarians, and this role has been proposed to represent the ancestral $\beta$-catenin function in early embryogenesis of metazoans (Wikramanayake et al., 2003). It is unknown if $\beta$-catenin signaling has a role in endoderm specification in Platynereis.

\section{Summary and future directions}

Comparisons among spiralians can reveal developmental changes that influence the evolution of novel forms. In this review, we focused on several examples of variation in spiralian development. Recent studies in Platynereis, Capitella and some clitellates have uncovered notable variation in fate maps, patterns of cleav- age, mechanisms of cell fate specification, organizing activity, and differences in molecular patterning. Some represent intra-clade variation within annelids, and others hint at possible differences between annelids and mollusks. Due to limited sampling, it is too early to draw firm conclusions about general trends. Additionally, there may be additional variation still to discover. Studies in other spiralians, including additional annelid representatives of both the Errantia and the Sedentaria clades are needed to investigate intra- vs. interclade variation. Such studies will help determine whether differences identified in either Platynereis or Capitella are conserved among annelids. It has been argued that heterochrony is a dominant force of evolutionary change (Gould, 1985, Raff et al., 1991), yet some changes discussed here are not just simple changes in developmental timing with respect to those of the ancestor. For example, the change in the fate map of $4 \mathrm{~d}$ in Capitella does not represent a simple case of complete cell fate change, since it generates some but not all of the cell types typically generated by $4 d$. Specifically, $4 d$ generates the germ line, anus and a few muscle fibers in Capitella, but does not generate the mesodermal bands that instead arise from $3 c$ and $3 d$. The examples described in this review hint that within the spiralian development program, there is ample variation and that the apparent paradox of how a similar, highly stereotypical cleavage program gives rise to such diversity of larval and adult forms may not be such a paradox after all.

Future studies should also include investigations into molecular mechanisms controlling spiralian development since there is still much to be learned. Several recent technical advances will make it realistic to perform such mechanistic studies in a broad range of animals. The application of RNAi knockdown approaches in Enchytraeus and morpholino-mediated knockdown in Helobdella demonstrates that functional genomics are possible in annelids (Takeo et al., 2010, Woodruff et al., 2007). In addition, recent development of reverse genetic tools using TALENs in Platynereis (Bannister et al., 2014), or use of CRISPR technology (Pennisi, 2013) holds great promise. The rapid advancement of sequencing technologies and drastic reduction in sequencing costs has also benefited the field. The first generation of genomes and transcriptomes, along with the needed resolving power of phylogenomics has been applied to this ancient clade (Bely, 2006, Henry et al., 2010, Lambert et al., 2010, Simakov et al., 2013). Each of these techniques requires effort to develop for new systems, but they are within reach, and together, they remove barriers towards mechanistic investigations in less-studied animals. Utilizing these techniques will certainly benefit our understanding of the evolution of developmental mechanisms in the most diverse bilaterian animal clade. It will be exciting to see what discoveries lay ahead.

A big challenge ahead is to try to link variation during early development with differences in the adult body plan. Without this link, one must consider that the observed natural variation has no impact on changes in morphology. If this is the case, the variability discussed in this review may very well be examples of 'developmental system drift' (True and Haag, 2001). True and Haag define 'developmental system drift' as the divergence of genetic regulation or morphogenetic processes that generate a homologous morphological structure. A well-characterized example is found in the development of the vulva in two nematodes, Caenorhabditis elegans and Pristionchus pacificus (Sommer, 2012). In both species, the vulva, an egg-laying structure, develops from the same set of three ectodermal precursor cells, and the vulva or 'outcome' 
is a homologous organ. However, distinct cell signaling pathways are used for vulval induction in the two species. Vulval formation requires an inductive signal from a nearby cell, the AC. In Caenorhabditis elegans, the AC secretes an EGF-type ligand critical for specification of the vulval precursor cells, and in P. pacificus, Wnt signaling specifies formation of the vulva. Alternatively, some of the described examples of variation may reflect divergent developmental pathways leading to nonhomologous structures. To distinguish between these alternatives, a detailed mechanistic understanding of the molecules controlling early developmental events in multiple species is needed to be able to compare the functional changes between two species (Sommer, 2012). Careful and detailed studies of variation during early development are a necessary first step to try to understand the evolution of developmental mechanisms in one of the largest and most diverse animal assemblages.

\section{Acknowledgements}

I thank Aldine Amiel for imaging the panels used for Fig. 2 construction, Alexa Bely for discussions, and Dede Lyons for recommending the quote from Child. I thank Danielle de Jong, Alexis Lanza and two anonymous reviewers for helpful comments that significantly improved the manuscript.

\section{References}

ACKERMANN, C., DORRESTEIJN, A. and FISCHER, A. (2005). Clonal domains in postlarval Platynereis dumerilii (Annelida: Polychaeta). J Morphol 266: 258-280.

AMIEL, A.R., HENRY, J.Q. and SEAVER, E.C. (2013). An organizing activity is required for head patterning and cell fate specification in the polychaete annelid Capitella teleta: new insights into cell-cell signaling in Lophotrochozoa. Dev Biol 379: 107-122.

BANNISTER, S., ANTONOVA, O., POLO, A., LOHS, C., HALLAY, N., VALINCIUTE, A., RAIBLE, F. and TESSMAR-RAIBLE, K. (2014). TALENs Mediate Efficient and Heritable Mutation of Endogenous Genes in the Marine Annelid Platynereis dumerilii. Genetics 197: 77-89.

BELY, A.E. (2006). Distribution of segment regeneration ability in the Annelida. Integr Comp Biol 46: 508-518.

BELY, A.E., ZATTARA, E.E. and SIKES, J.M. (2014). Regeneration in spiralians: evolutionary patterns and developmental processes. Int. J. Dev. Biol. 58: 623-634.

BISSEN, S.T. and WEISBLAT, D.A. (1989). The durations and compositions of cell cycles in embryos of the leech, Helobdella triserialis. Development 106: 105-118.

CHILD, C.M. (1900). The early development of Arenicola and Sternaspis. Archiv fur Entwicklungsmechanik der Organismen 9: 587-723.

CLEMENT, A.C. (1952). Experimental studies on germinal localization in llyanassa. I. The role of the polar lobe in determination of the cleavage pattern and its influence on later development. J Exp Zool 121: 593-626.

CLEMENT, A.C. (1962). Development of Illyanasa following the removal of the D macromere at successive cleavage stages. J Exp Zool 149: 193-216.

CONKLIN, E.G. (1897). The embryology of Crepidula, a contribution to the cell lineage and early development of some marine gasteropods. J Morphol 13: 1-226.

COSTELLO, D.P. (1945). Experimental studies of germinal localization in nereis. I. The development of isolated blastomeres. J Exp Zool 100: 19-66.

CRAMPTON, H.E. (1896). Experimental studies on gasteropod development. Arkiv Ent Mech Org 3: 1-19.

DAMEN, P. (1994). Cell-lineage, and specification of developmental fate and dorsoventral organisation in the mollusc Patella vulgata, (ed. University of Utrecht, the Netherlands).

DEVRIES, J. (1968). Les premieres etapes de la segmentation (formation de la jeune blastule) chez le lombricien, Eisenia foetida. Bull Soc Zool Fr 93: 87-97.

DEVRIES, J. (1973). The formation and fate of the embryonic layers in the earthworm Eisinia foetida (annelida, oligochaeta). Arch Anat Microsc Morphol Exp 62: 15-38.

DOHLE, W. (1999). The ancestral cleavage pattern of the clitellates and its phylogenetic deviations. Hydrobiologia 402: 267-283.
DORRESTEIJN, A.W.C. (1990). Quantitative analysis of cellular differentiation during early embryogenesis of Platynereis dumerilii. Roux's Arch Dev Biol 199: 14-30.

DUNN, C.W., HEJNOL, A., MATUS, D.Q., PANG, K., BROWNE, W.E., SMITH, S.A. SEAVER, E., ROUSE, G.W., OBST, M., EDGECOMBE, G.D. et al., (2008). Broad phylogenomic sampling improves resolution of the animal tree of life. Nature 452: 745-749.

EDGECOMBE, G.D., GIRIBET, G., DUNN, C.W., HEJNOL, A., KRISTENSEN, R.M., NEVES, R.C., ROUSE, G.W., WORSAAE, K. and SORENSEN, M.V. (2011). Higher-level metazoan relationships: recent progress and remaining questions. Org Divers Evol 11: 151-172.

EISIG, H. (1899). Zur Entwicklungsgeschichte der Capitelliden. Mittheilungen Aus der Zoologischen Station Zu Neapel 13: 1-292.

FISCHER, A.H. and ARENDT, D. (2013). Mesoteloblast-like mesodermal stem cells in the polychaete annelid Platynereis dumerilii (Nereididae). J Exp Zool B Mol Dev Evol 320: 94-104.

GEILENKIRCHEN, W.L.M., VERDONK, N.H. and TIMMERMANS, L.P.M. (1970). Experimental studies on morphogenetic factors localized in the first and second polar lobe of Dentalium eggs. J Embryol Exp Morphol 23: 237-243.

GIRIBET, G. (2008). Assembling the lophotrochozoan (=spiralian) tree of life. Philos Trans R Soc Lond B Biol Sci 363: 1513-1522.

GLINE, S.E., NAKAMOTO, A., CHO, S.J., CHI, C. and WEISBLAT, D.A. (2011). Lineage analysis of micromere $4 d$, a super-phylotypic cell for Lophotrochozoa, in the leech Helobdella and the sludgeworm Tubifex. Dev Biol 353: 120-133.

GOTO, A., KITAMURA, K., ARAI, A. and SHIMIZU, T. (1999). Cell fate analysis of teloblasts in the Tubifex embryo by intracellular injection of HRP. Dev Growth Differ 41: 703-713.

GOULD, S.J. (1985). Ontogeny and Phylogeny. Belknap Press.

GOULDING, M.B. (2001). Comparative and experimental analysis of precocious cell-lineage diversification in the embryonic dorsoventral axis of the gastropod Ilyanassa., vol. PhD (ed. University of Texas, Austin, USA).

HALANYCH, K.M., DAHLGREN, T.G. and MCHUGH, D. (2002). Unsegmented annelids? Possible origins of four lophotrochozoan worm taxa. Integr Comp Biol 42: 678-84.

HEJNOL, A., OBST, M., STAMATAKIS, A., OTT, M., ROUSE, G.W., EDGECOMBE, G.D., MARTINEZ, P., BAGUNA, J., BAILLY, X., JONDELIUS, U. et al., (2009). Assessing the root of bilaterian animals with scalable phylogenomic methods. Proc Biol Sci 276: 4261-4270.

HENRY, J.J. (1986). The role of unequal cleavage and the polar lobe in the segregation of developmental potential during first cleavage in the embryo of Chaetopterus variopedatus. Roux's Arch Dev Biol 195: 103-116.

HENRY, J.J. and MARTINDALE, M.Q. (1987). The organizing role of the D quadrant as revealed through the phenomenon of twinning in the polychaete Chaetopterus variopedatus. Roux's Arch Dev Biol 196: 499-510.

HENRY, J.J. and PERRY, K.J. (2008). MAPK activation and the specification of the D quadrant in the gastropod mollusc, Crepidula fornicata. Dev Bio/313: 181-195.

HENRY, J.J., PERRY, K.J., FUKUI, L. and ALVI, N. (2010). Differential localization of mRNAs during early development in the mollusc, Crepidula fornicata. Integr Comp Biol 50: 720-733.

HENRY, J.Q., PERRY, K.J. and MARTINDALE, M.Q. (2006). Cell specification and the role of the polar lobe in the gastropod mollusc Crepidula fornicata. Dev Biol 297: 295-307.

HENRY, J.Q., PERRY, K.J., WEVER, J., SEAVER, E. and MARTINDALE, M.Q. (2008) Beta-catenin is required for the establishment of vegetal embryonic fates in the nemertean, Cerebratulus lacteus. Dev Biol 317: 368-379.

HUANG, F.Z., KANG, D., RAMIREZ-WEBER, F.A., BISSEN, S.T. and WEISBLAT, D.A. (2002). Micromere lineages in the glossiphoniid leech Helobdella. Development 129: 719-732.

KALETTA, T., SCHNABEL, H. and SCHNABEL, R. (1997). Binary specification of the embryonic lineage in Caenorhabditis elegans. Nature 390: 294-298.

KOOP, D., RICHARDS, G.S., WANNINGER, A., GUNTER, H.M. and DEGNAN, B.M. (2007). The role of MAPK signaling in patterning and establishing axial symmetry in the gastropod Haliotis asinina. Dev Biol 311: 200-212.

KORSWAGEN, H.C. (2002). Canonical and non-canonical Wnt signaling pathways in Caenorhabditis elegans: variations on a common signaling theme. Bioessays 24: $801-810$ 
LAMBERT, J.D. (2008). Mesoderm in spiralians: the organizer and the 4 d cell. J Exp Zool B Mol Dev Evol 310: 15-23.

LAMBERT, J.D., CHAN, X.Y., SPIECKER, B. and SWEET, H.C. (2010). Characterizing the embryonic transcriptome of the snail llyanassa. Integr Comp Biol50: 768-777.

LAMBERT, J.D. and NAGY, L.M. (2001). MAPK signaling by the D quadrant embryonic organizer of the mollusc llyanassa obsoleta. Development 128: 45-56.

LAMBERT, J.D. and NAGY, L.M. (2003). The MAPK cascade in equally cleaving spiralian embryos. Dev Biol 263: 231-241.

LARTILLOT, N., LESPINET, O., VERVOORT, M. and ADOUTTE, A. (2002). Expression pattern of Brachyury in the mollusc Patella vulgata suggests a conserved role in the establishment of the AP axis in Bilateria. Development 129: 1411-1421.

LILLIE, F.R. (1906). Observations and experiments concerning the elementary phenomena of embryonic development in Chaetopterus. J Exp Zool 3: 153-268.

LIN, R., HILL, R.J. and PRIESS, J.R. (1998). POP-1 and anterior-posterior fate decisions in C. elegans embryos. Cell 92: 229-239.

LYONS, D.C., PERRY, K.J., LESOWAY, M.P. and HENRY, J.Q. (2012). Cleavage pattern and fate map of the mesentoblast, $4 \mathrm{~d}$, in the gastropod Crepidula: a hallmark of spiralian development. EvoDevo 3: 21.

MEAD, A.D. (1897). The early development of marine annelids. J. Morphology XIII: 227-327.

MEYER, N.P., BOYLE, M.J., MARTINDALE, M.Q. and SEAVER, E.C. (2010). A comprehensive fate map by intracellular injection of identified blastomeres in the marine polychaete Capitella teleta. EvoDevo 1: 8.

MEYER, N.P. and SEAVER, E.C. (2010). Cell lineage and fate map of the primary somatoblast of the polychaete annelid Capitella teleta. IntegrCompBiol50:756-767.

NAKAMOTO, A., NAGY, L.M. and SHIMIZU, T. (2011). Secondary embryonic axis formation by transplantation of $D$ quadrant micromeres in an oligochaete annelid. Development 138: 283-290.

NELSON, J.A. (1904). The early development of Dinophilus: a study in cell-lineage. Proc Acad Nat Sci Philadelphia 56: 687-737.

NOVIKOFF, A.B. (1938). Embryonic determination in the annelid Sabellaria vulgaris. II. Transplantion of polar lobes and blastomeres as a test of their inducing capacities. Biol Bull 74: 211-234.

PENNERS, A. (1922). Die Furchung von Tubifex rivulorum Lam. Zool Jb Abt Anat Ontog 43: 323-367.

PENNISI, E. (2013). The CRISPR craze. Science 341: 833-836.

PERNET, B., AMIEL, A. and SEAVER, E.C. (2012). Effects of maternal investment on larvae and juveniles of the annelid Capitella teleta determined by experimental reduction of embryo energy content. Inverteb. Biol. 131: 82-95.

PFEIFER, K., SCHAUB, C., DOMSCH, K., DORRESTEIJN, A. and WOLFSTETTER, G. (2014). Maternal inheritance of twist and analysis of MAPK activation in embryos of the polychaete annelid Platynereis dumerilii. PLoS One 9: e96702.

PHILIPPE, H., DERELLE, R., LOPEZ, P., PICK, K., BORCHIELLINI, C., BOURYESNAULT, N., VACELET, J., RENARD, E., HOULISTON, E., QUEINNEC, E. et al., (2009). Phylogenomics revives traditional views on deep animal relationships. Curr Biol 19: 706-712.

RABINOWITZ, J.S., CHAN, X.Y., KINGSLEY, E.P., DUAN, Y. and LAMBERT, J.D. (2008). Nanos is required in somatic blast cell lineages in the posterior of a mollusk embryo. Curr Biol 18: 331-336.

RAFF, R.A., WRAY, G.A. and HENRY, J.J. (1991). Implications of radical evolutionary changes in early development for concepts of developmental constraint. In New Perspectives on Evolution, vol. 4 (ed. WARREN, L. and KOPROWSKI, H.). Wiley-Liss, New York, pp.189-207.

RENDER, J.A. (1983). The second polar lob of the Sabellaria cementarium embryo plays an inhibitory role in apical tuft formation. Roux's Arch Dev Biol 192: 120-129.

RENDER, J.A. (1997). Cell fate maps in the Illyanassa obsoleta embryo beyond the third division. Dev Biol 189: 301-310.

ROUSE, G.W. and PLEIJEL, F. (2001). Polychaetes. Oxford University Press, Oxford; New York.

SANDIG, M. and DOHLE, W. (1988). The cleavage pattern in the leech Theromyzon tessulatum (Hirudinea, Glossiphoniidae). J Morphol 196: 217-252.

SCHNABEL, R., HUTTER, H., MOERMAN, D. and SCHNABEL, H. (1997). Assessing normal embryogenesis in Caenorhabditis elegans using a 4D microscope: variability of development and regional specification. Dev Biol 184: 234-265.
SCHNEIDER, S. (1992). A morphometric comparison of dissimilar early development in sibling species of Platynereis (Annelida, Polychaeta). Roux's Arch Dev Biol 201: 243-256.

SCHNEIDER, S.Q. and BOWERMAN, B. (2007). beta-Catenin asymmetries after all animal/vegetal- oriented cell divisions in Platynereis dumerilii embryos mediate binary cell-fate specification. Dev Cell 13: 73-86.

SEAVER, E.C. (2003). Segmentation: mono- or polyphyletic. Int J Dev Bio/47:583-595

SEAVER, E.C., THAMM, K. and HILL, S.D. (2005). Growth patterns during segmentation in the two polychaete annelids, Capitella sp. I and Hydroides elegans: comparisons at distinct life history stages. Evol Dev 7: 312-326.

SHANKLAND, M. and SAVAGE, R. (1997). Annelids, the Segmented Worms. In Embryology Constructing the Organism, (ed. GILBERT, S. F. and RAUNIO, A. M.). Sinaur Associates, Inc., Sunderland, MA, pp.219-235.

SHANKLAND, M. and SEAVER, E.C. (2000). Evolution of the bilaterian body plan: what have we learned from annelids? Proc Natl Acad Sci USA 97: 4434-4437.

SIMAKOV, O., MARLETAZ, F., CHO, S.J., EDSINGER-GONZALES, E., HAVLAK, P., HELLSTEN, U., KUO, D.H., LARSSON, T., LV, J., ARENDT, D. et al., (2013). Insights into bilaterian evolution from three spiralian genomes. Nature 493:526-531.

SOMMER, R.J. (2012). Evolution of regulatory networks: nematode vulva induction as an example of developmental systems drift. Adv Exp Med Biol 751: 79-91.

STRUCK, T.H., PAUL, C., HILL, N., HARTMANN, S., HOSEL, C., KUBE, M., LIEB, B., MEYER, A., TIEDEMANN, R., PURSCHKE, G. et al., (2011). Phylogenomic analyses unravel annelid evolution. Nature 471: 95-98.

STRUCK, T.H., SCHULT, N., KUSEN, T., HICKMAN, E., BLEIDORN, C., MCHUGH, D. and HALANYCH, K.M. (2007). Annelid phylogeny and the status of Sipuncula and Echiura. BMC Evol Biol 7: 57.

STRUCK, T.H., WEY-FABRIZIUS, A.R., GOLOMBEK, A., HERING, L., WEIGERT, A., BLEIDORN, C., KLEBOW, S., IAKOVENKO, N., HAUSDORF, B., PETERSEN, M. et al., (2014). Platyzoan Paraphyly Based on Phylogenomic Data Supports a Noncoelomate Ancestry of Spiralia. Mol Biol Evol 31:1833-1849.

SWEET, H.C. (1998). Specification of first quartet micromeres in llyanassa involves inherited factors and position with respect to the inducing D macromere. Development 125: 4033-4044.

TAKEO, M., YOSHIDA-NORO, C. and TOCHINAI, S. (2010). Functional analysis of grimp, a novel gene required for mesodermal cell proliferation at an initial stage of regeneration in Enchytraeus japonensis (Enchytraeidae, Oligochaete). Int $J$ Dev Biol 54: 151-160.

THAMM, K. (2007). Involvement of the Notch-signaling pathway in the development of the two polychaete annelids Capitella sp. I and Platynereis dumerilii, (ed., University of Geissen, Germany)

THOMAS, M.B. (1986). Embryology of the Turbellariaand its phylogenetic significance. Hydrobiologia 132: 105-115.

TREADWELL, A.I. (1901). The cytogeny of Podarke obscura Verrill. Journal of Morphology 17: 399-487.

TRUE, J.R. and HAAG, E.S. (2001). Developmental system drift and flexibility in evolutionary trajectories. Evol Dev 3: 109-119.

TYLER, A. (1930). Experimental production of double embryos in annelids and mollusks. J Exp Zool 57: 347-407.

VERDONK, N.H. (1968). The determination of bilateral symmetry in the head region of Lymnaea stagnalis. Acta Embryol Morph exp 10: 211-227.

WADESON, P.H. and CRAWFORD, K. (2003). Formation of the blastoderm and yolk syncytial layer in early squid development. Biol Bull 205: 179-180.

WEIGERT, A., HELM, C., MEYER, M., NICKEL, B., ARENDT, D., HAUSDORF, B., SANTOS, S.R., HALANYCH, K.M., PURSCHKE, G., BLEIDORN, C. et al., (2014). Illuminating the Base of the Annelid Tree Using Transcriptomics. Mol Biol Evol 31:1391-1401.

WEISBLAT, D.A., KIM, S.Y. and STENT, G.S. (1984). Embryonic origins of cells in the leech Helobdella triserialis. Dev Biol 104: 65-85.

WEISBLAT, D.A., SAWYER, R.T. and STENT, G.S. (1978). Cell lineage analysis by intracellular injection of a tracer enzyme. Science 202: 1295-1298.

WEISBLAT, D.A. and SHANKLAND, M. (1985). Cell lineage and segmentation in the leech. Philos Trans R Soc Lond B Biol Sci 312: 39-56.

WEISBLAT, D.A., ZACKSON, S.L., BLAIR, S.S. and YOUNG, J.D. (1980). Cell lineage analysis by intracellular injection of fluorescent tracers. Science 209: 1538-1541. 
WHITMAN, C.O. (1887). A contribution to the history of the germ-layers in Clepsine. J Morphol 1: 105-182.

WIKRAMANAYAKE, A.H., HONG, M., LEE, P.N., PANG, K., BYRUM, C.A., BINCE, J.M., XU, R. and MARTINDALE, M.Q. (2003). An ancient role for nuclear beta-catenin in the evolution of axial polarity and germ layer segregation. Nature 426: 446-450.

WILSON, E.B. (1892). The cell-lineage of Nereis. A contribution to the cytogeny of the Annelid body. J Morphol 6: 361-480.

WILSON, E.B. (1898). Considerations on cell-lineage and ancestral reminiscence.
Ann N Y Acad Sci XI: 1-27

WILSON, E.B. (1904). Experimental studies on germinal localization. I. The germregions in the egg of Dentalium. J Exp Zool 1: 1-72.

WOODRUFF, J.B., MITCHELL, B.J. and SHANKLAND, M. (2007). Hau-Pax3/7A is an early marker of leech mesoderm involved in segmental morphogenesis, nephridial development, and body cavity formation. Dev Biol 306: 824-837.

ZACKSON, S.L. (1982). Cell clones and segmentation in leech development. Cell 31: 761-770. 


\section{Further Related Reading, published previously in the Int. J. Dev. Biol.}

Brachyury, Tbx2/3 and sall expression during embryogenesis of the indirectly developing polychaete Hydroides elegans Cesar Arenas-Mena

Int. J. Dev. Biol. (2013) 57: 73-83

Hydra, a model system to trace the emergence of boundaries in developing eumetazoans Angelika Böttger and Monika Hassel

Int. J. Dev. Biol. (2012) 56: 583-591

The head organizer in Hydra

Hans R. Bode

Int. J. Dev. Biol. (2012) 56: 473-478

Planarian embryology in the era of comparative developmental biology José M. Martín-Durán, Francisco Monjo and Rafael Romero Int. J. Dev. Biol. (2012) 56: 39-48

Planarian regeneration: a classic topic claiming new attention

Emili Saló and Kiyokazu Agata

Int. J. Dev. Biol. (2012) 56: 1-4

Function and specificity of Hox genes

David Foronda, Luis F. de Navas, Daniel L. Garaulet and Ernesto Sánchez-Herrero Int. J. Dev. Biol. (2009) 53: 1409-1419

Segmentation, metamerism and the Cambrian explosion Juan Pablo Couso

Int. J. Dev. Biol. (2009) 53: 1305-1316

A history of Evo-Devo research in Spain

Jaume Baguñà

Int. J. Dev. Biol. (2009) 53: 1205-1217

The first bilaterian organisms: simple or complex? New molecular evidence J Baguna, I Ruiz-Trillo, J Paps, M Loukota, C Ribera, U Jondelius, M Riutort Int. J. Dev. Biol. (2001) 45: S133-S134

Characterization of novel F-actin envelopes surrounding nuclei during cleavage of a polychaete worm.

S Jacobsohn

Int. J. Dev. Biol. (1999) 43: 19-26

5 yr ISI Impact Factor $(2011)=2.959$
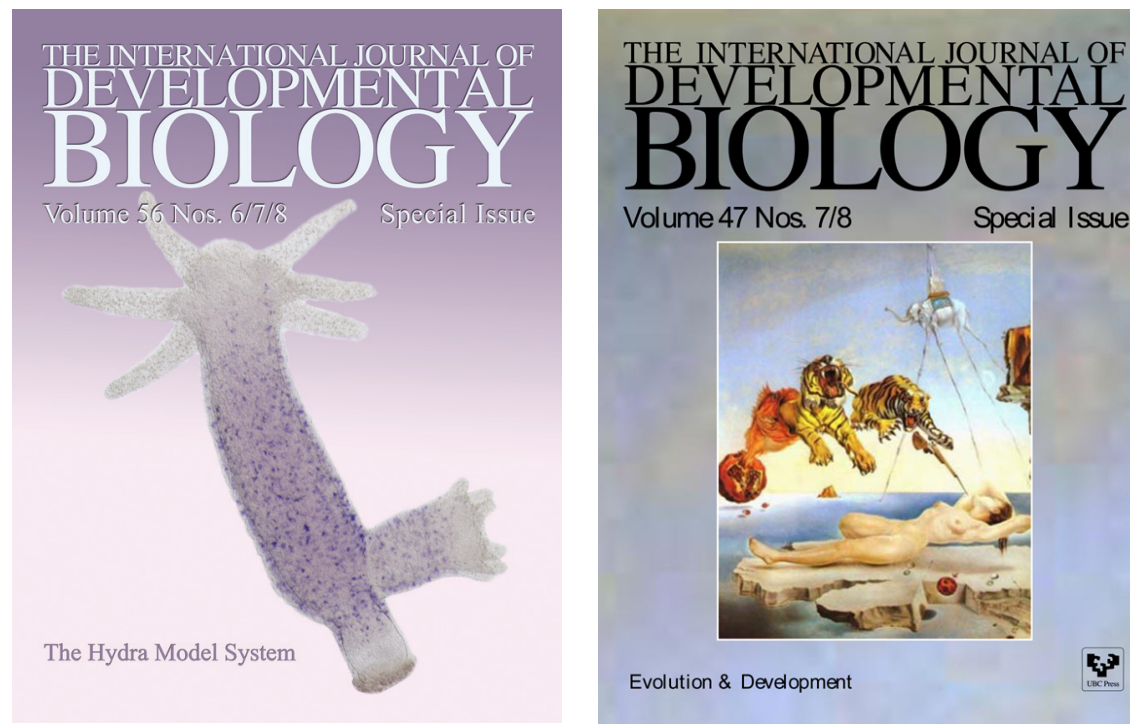

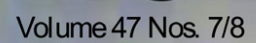

Special Issue

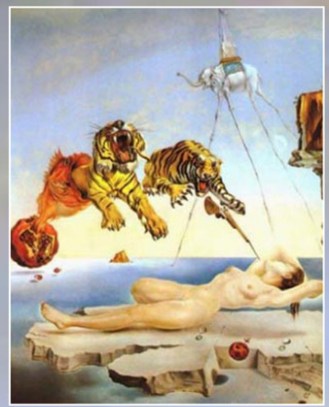

Evolution \& Development
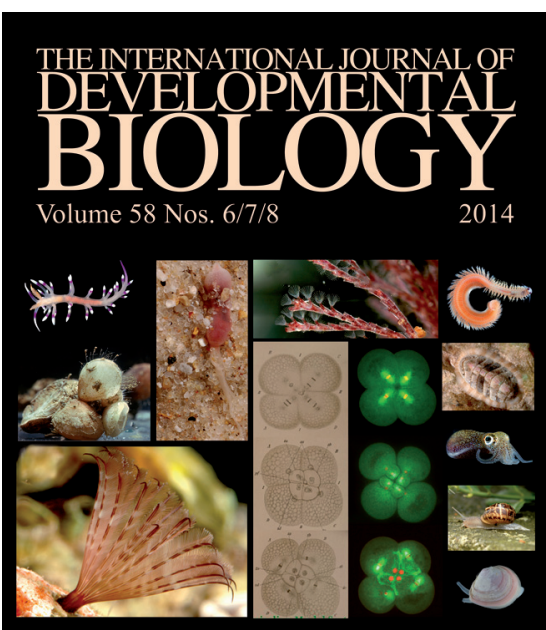

Spiralian Model Systems
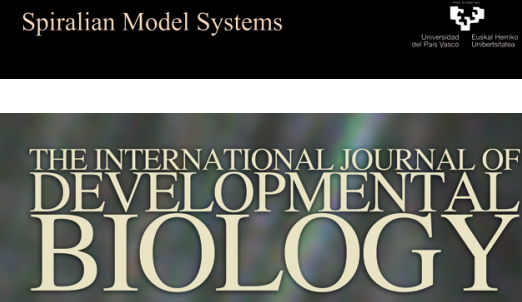

Volume 56 Nos. $1 / 2 / 3$

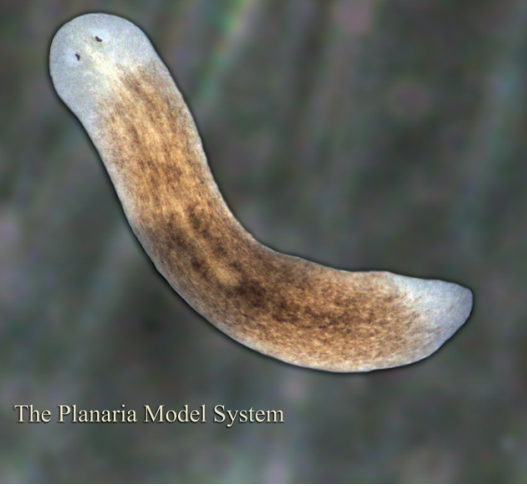

